\title{
Mutational Analysis of the Pro-opiomelanocortin Gene in French Obese Children Led to the Identification of a Novel Deleterious Heterozygous Mutation Located in the $\alpha$-Melanocyte Stimulating Hormone Domain
}

\author{
BEATRICE DUBERN, CECILE LUBRANO-BERTHELIER, MONICA MENCARELLI, BARAN ERSOY, MARIE-LAURE FRELUT, \\ DOMINIQUE BOUGLÉ, BRUNO COSTES, CHANTAL SIMON, PATRICK TOUNIAN, CHRISTIAN VAISSE, AND KARINE CLEMENT \\ Center of Research on Human Nutrition Ile de France [B.D., C.L.-B., M.M., P.T., K.C.], 75004 Paris, France; Inserm, U872, Nutriomique \\ (team 7), Cordelier Research Center [B.D., C.L.-B., M.M., P.T., K.C.], 75004 Paris, France; University Pierre et Marie Curie-Paris 6 \\ [B.D., C.L.-B., M.M., P.T., K.C.], 75004 Paris, France; AP-HP [C.L.-B., K.C.], Pitié Salpêtrière, Endocrinology and Nutrition \\ Department, Hôtel-Dieu 75004 Paris, France; AP-HP [B.D., P.T.], Trousseau Hospital, Department of Pediatric Nutrition and \\ Gastroenterology, 75012 Paris, France; Diabetes Center and Department of Medicine [B.E., C.V.], University of California San \\ Francisco, San Francisco CA 94143, USA; French Red Cross [M.-L. F.], Pediatric Therapeutic Center of Margency, 95580 Margency, \\ France; Paediatric Department [D.B.], Caen teaching hospital, 14027 Caen, France; AP-HP [B.C.], Department of biochemistry and \\ genetics, Henri-Mondor Hospital 94010 Créteil, France; INSERM [B.C.], U841, 94010 Créteil, France; Louis Pasteur University of \\ Strasbourg [C.S.], Medical School, EA1801, 67000, Strasbourg, France; Molecular Biology Laboratory [M.M.], Auxologic Italian
} Institute, 28900 Verbania, Italy

\begin{abstract}
The pro-opiomelanocotin (POMC) plays a key role in body weight regulation, where its derived peptides mediate leptin action via the hypothalamic melanocortin 4 receptor (MC4R). The pathogenic effects of POMC mutations have been challenged in obesity. Our aim was to assess the relevance of POMC mutations in a cohort of French obese and nonobese children. Direct sequencing of the POMC gene was performed in 322 obese and 363 control unrelated children. Functional studies for the novel Phe144Leu mutation included the response to $\alpha$-melanocyte stimulating hormone ( $\alpha \mathrm{MSH})$ and a competitive binding assay. POMC mutations were identified in $3.72 \%$ of obese [95\% confidence interval (CI): $1.66-5.80$ ] and $2.20 \%$ of control (95\% CI: $0.69-$ 3.71) subjects. The novel mutation located in the $\alpha \mathrm{MSH}$ region of the POMC gene (Phe144Leu) was found in one obese child and was transmitted by the obese father. Functional studies showed that MC4R activation in response to Leu144 $\alpha \mathrm{MSH}$ was almost completely abolished due to a dramatically altered binding of Leu144 $\alpha \mathrm{MSH}$ to MC4R. The frequency of POMC mutations is not significantly different between obese and control children in our cohort. The novel heterozygous mutation Phe144Leu leading to the absence of melanocortin signaling was associated with early-onset obesity suggesting its pathogenic role. (Pediatr Res 63: 211-216, 2008)
\end{abstract}

$\mathrm{T}$ he proopiomelanocortin (POMC) is a complex propeptide encoding a number of melanocortin peptides that are released by tissue-specific proteolytic processing. These pep-

Received May 15, 2007; accepted September 26, 2007.

Correspondence: Karine Clement, M.D., Ph.D., Inserm U872, Nutriomique, HôtelDieu Hospital, 1 place Notre-Dame, 75004 Paris, France; e-mail: karine.clement@psl.aphp.fr Programme Hospitalier de Recherche Clinique Direction de la Recherche Clinique/Assistance Publique-Hopitaux de Paris (contract grant number PHRC AOM 96088), BQR of Paris 6 University. Funding was obtained by the program GIP-ANR (No. 06-CPER-194-02). B.D. was supported by a grant from the AFERO (Association Française d'Etudes et de Recherches sur l'Obésité) and by a "Bourse Collery de l'Académie Nationale de Médecine." C.L.B. was supported by a fellowship from the Danone Institute (Prix Alimentation et Santé 2004). B.E. was supported by UCSF Endocrinology and Metabolism Training Grant. The work of B.E. and C.V. was supported by NIH DK068152-01.

B.D. and C.L.-B. equally contributed to this work. tides have important roles in a range of functions such as skin pigmentation, control of adrenal function, and body weight regulation via the leptin/melanocortin pathway (1). The production of POMC in the central nervous system is stimulated by leptin and its posttranslational process leads to the generation of different peptides (2). The nature of POMC-derived peptides depends on the type of endoproteolytic enzymes present in specific brain areas. In the anterior pituitary, the presence of the proconvertase (PC) 1 enzyme allows the production of adrenocorticotropic hormone (ACTH) and $\beta$-lipotropin peptides, while the simultaneous presence of PC1 and PC2 in the hypothalamus determines the production of $\alpha$-, $\beta-, \gamma$-melanocyte-stimulating hormone $(\alpha-, \beta-, \gamma \mathrm{MSH})$ and $\beta$-endorphins. POMC knockout mice become obese due to the loss of the anorexigenic action of $\alpha \mathrm{MSH}$ on melanocortin-4 receptor (MC4R) expressing neurons. They have no adrenal function because of the lack of ACTH production and present variable alterations in coat pigmentation due to the absence of $\alpha \mathrm{MSH}$ in the skin (3). The phenotype of POMC-deficient mice resembles that of patients with rare mutations that completely prevent POMC-derived peptide production. To date, six families with children carrying homozygous or compound heterozygous loss-of-function mutations in POMC have been described. The children in these families display a hypocortisolism, early-onset obesity, and variable alterations of skin and hair pigmentation, thereby defining a new rare syndrome of obesity associated with POMC deficiency $(4,5)$.

The POMC gene is located in the human chromosome 2, which is a region strongly linked with leptin levels and to a

\footnotetext{
Abbreviations: ACTH, corticotropin; MC4R, melanocortin 4 receptor; MSH, melanocyte-stimulating hormone; POMC, pro-opiomelanocortin; PC, proconvertase
} 
lesser extent with obesity (6-9). It was considered a strong positional candidate, and direct gene screening revealed several polymorphisms, generally with low frequency, located in both coding and noncoding regions (10). Variants of the POMC gene were found in German (11,12), Danish (13), Swedish (14), Italian $(15,16)$, and English $(17,18)$ obese children and young adults and in French diabetic and obese adults (19). These variations included base insertion or deletion, missense, or silent mutations and were generally uncommon. Most of these variants were not associated with obesityrelated phenotypes and generally had no functional consequences, except for mutations involving $\beta \mathrm{MSH}$ domain (Arg236Gly and Tyr221Cys) $(12,17,18)$. The frequency of the Arg236Gly mutation was shown to be mildly increased in U.K. obese children, and functional analyses revealed that this mutation prevents the normal processing of $\beta \mathrm{MSH}$ and $\beta$-endorphin, resulting in a fusion protein (17). Able to bind MC4R, this aberrant peptide leads to a decreased activation of the receptor. Recently, the mutation Tyr221Cys, also located in the $\beta \mathrm{MSH}$ domain of POMC, was implicated in early-onset obesity with deleterious in vitro functional effects $(12,18)$. Those findings suggested that $\beta \mathrm{MSH}$ might play a critical role in weight regulation in humans. Thus, further investigations of the POMC gene in obese and nonobese populations are needed to determine the contributing role of POMC gene variants in human obesity.

In the present study, we report the mutational analysis of the POMC gene in a French cohort of 322 obese children and 363 controls. We also describe a novel heterozygous mutation in the $\alpha \mathrm{MSH}$ domain of the POMC gene associated with earlyonset obesity and with deleterious in vitro functional effects.

\section{MATERIALS AND METHODS}

Direct POMC gene sequencing. This study was approved by the local ethics committee, and informed consent was obtained from all participating subjects. The genomic DNA of all subjects was isolated from $10 \mathrm{~mL}$ of venous whole blood (Wizard Genomic DNA Purification Kit, Promega Madison, WI). Direct sequencing (Sequencer Applied Biosystem) of the coding region of the POMC gene was performed in 322 unrelated obese children and in 363 nonobese children. Obese children [mean age, 12.8 y \pm 2.8 standard deviations (SDs); mean body mass index (BMI) $Z$ score $=4.3 \pm 1.2 \mathrm{SDs}$; BMI $Z$ score range, 2.0-10.2 SDs] were prospectively recruited between 2001 and 2004 in three different departments of pediatric nutrition located in Paris, Caen, and Margency, France [as described in Dubern et al. (20)]. In the present study, obesity was defined as a BMI $Z$ score at least 2 SDs above the mean age and sex-specific BMI values in children in France (21). The control group included 363 nonobese children (mean age, 11.5 y $\pm 0.6 \mathrm{SD}$; mean BMI $Z$ score $=0.2 \pm 1.0 \mathrm{SD}$; BMI $Z$ score range, -2.96 to $1.93 \mathrm{SDs}$ ). These children were part of a randomized, controlled ongoing field trial (ICAPS) in middle school's first-level adolescents from eight randomly selected schools in the department of the Bas-Rhin (Eastern France) (22).

Genotyping of the Phe144Leu POMC mutation in the proband's family was also performed by direct sequencing (Sequencer Applied Biosystem) of the coding regions of the POMC gene. Primers and conditions can be provided upon request. Nucleotides and amino acids were numbered according to GenBank accession numbers V01510 and NP 000930, respectively.

Clinical and biochemical data. All obese patients underwent a physical examination with anthropometric measurements and Tanner stage evaluation by the same investigator in each center. Height and weight curves were obtained from the medical health records of the subjects.

In the patient carrying the Phe144Leu mutation, body composition (fatfree mass and body fat) was measured using whole-body dual-energy x-ray absorptiometry (Hologic QDR 2000 unit, Waltham, MA). The percentage body fat was calculated as the ratio of total body fat mass over total body mass. Blood samples were collected in the morning after an overnight fast.
Total cholesterol and triacylglycerol were measured using an enzymatic assay (Boerhinger, Mannheim, Germany). Plasma leptin concentrations were measured by radioimmunoassay (RIA) (LINCO Research, Inc., St. Louis, MO). Oral glucose tolerance test was performed by giving $1.75 \mathrm{~g}$ glucose $/ \mathrm{kg}$ body weight (maximum, $75 \mathrm{~g}$ ). Plasma glucose and insulin concentrations were measured in the fasting state and 30 and 120 min after glucose ingestion using the glucose oxidase method and a RIA with polyclonal antibodies (INSI-PR, CIS Bio International, Gif-sur-Yvette, France), respectively. Hypothalamicpituitary-adrenal axis exploration included urinary free cortisol and a dynamic test of adrenal axis with measurements of serum cortisol and ACTH by standard immunoassays. To explore thyroid axis, serum free thyroxine $\left(\mathrm{T}_{4}\right)$ and thyroid-stimulating hormone (TSH) were measured by standard immunoassays. Basal resting metabolic rate was performed using indirect calorimetry (Deltatrac II monitor, Datex Instrumentarium Corp., Helsinki, Finland).

Human MC4R (hMC4R) activation by the $\mathrm{\alpha MSH}$ product of Phe144leu POMC. Leu144 $\alpha$ MSH (Leu at position 7 of $\alpha \mathrm{MSH}$ ) and Phe144 $\alpha$ MSH (Phe at position 7) were synthesized and purified by high-performance liquid chromatography (Genemed Synthesis Inc., South San Francisco, CA). MC4R activity was measured by analyzing its ability to activate expression of a cyclic adenosine monophosphate (cAMP)-inducible luciferase gene in HEK 293 (23). HEK 293 cells stably expressing a cAMP-inducible luciferase gene were transiently transfected with the hMC4R and stimulated for $6 \mathrm{~h}$ with medium alone, increasing amounts of Phe $144 \alpha \mathrm{MSH}$ or Leu1 $44 \alpha \mathrm{MSH}$, after which luciferase activity was measured as previously described (23). Data points represent means of five determinations and error bars indicate SDs.

Competitive binding assay. HEK 293 cells stably transfected with the hMC4R were incubated with $\left[{ }^{125} \mathrm{I}\right] \mathrm{NDP} \alpha \mathrm{MSH}$ in the presence of increasing concentrations of Phe $144 \alpha$ MSH or Leu $144 \alpha$ MSH. Results are expressed as a percentage of total specific binding (Bmax). The curve is fitted using nonlinear regression analysis and one-site competition model (GraphPad Prism, graph software, San Diego, CA). Each point is the mean of triplicate values. Error bars indicate SDs.

\section{RESULTS}

Frequency of POMC mutations in obese and lean French children and identification of a patient carrying the Phe144Leu POMC mutation.

By screening 322 severely obese children for POMC mutations, nine mutations were identified (Asp53Gly, Gly96Cys, Pro132Ala, Arg236Gly, Glu214Gly, Ala195Thr, Leu209Pro, Phe87Leu, Phe144Leu) in 12 unrelated individuals (3.72\%, 95\% CI: 1.66-5.80]). Among them, six have not been previously reported (Asp53Gly, Phe87Leu, Gly96Cys, Pro132Ala, Phe144Leu, Leu209Pro). In the control group, two novel mutations (Asn91Ser, Glu57Lys) were uniquely detected, whereas two mutations (Glu214Gly, Ala195Thr) were found in both obese and control populations (Table 1 and Fig. 1). Four obese patients and one lean control were carriers of the Asp53Gly mutation (1.24\%). Overall, the frequency of POMC gene variations was not significantly different between obese (3.72\%, 95\% CI: $1.66-5.80)$ and controls $[2.20 \%, 95 \%$ CI: $0.69-3.71, p=$ not significant (NS)] in this group of French children. Clinical and biological characteristics of POMC mutation carriers (obese and controls) are shown in Table 2. No difference in weight and BMI $Z$ score was observed between POMC genetic variant carriers and noncarriers in the obese and lean groups, respectively (data not shown).

Because most of the detected mutations occurred in regions of the POMC propeptide with uncertain biological functions, we concentrated our study on the novel heterozygous missense mutation Phe144Leu located in the $\alpha \mathrm{MSH}$ coding region of POMC gene. The Phe144Leu mutation was detected in only one obese child and was absent in the control population. Segregation analysis of the mutation in the family showed that the mutation was present in the obese father (Fig. 2A). The 
Table 1. Frequency of POMC gene variations in obese and control children

\begin{tabular}{lccc}
\hline Nucleotide change & Amino acid change & Obese $(n=322)$ & Controls $(n=373)$ \\
\hline $158 \mathrm{a}>\mathrm{g}$ & Asp53Gly & $4(1.24 \%)$ & $1(0.27 \%)$ \\
$287 \mathrm{c}>\mathrm{t}$ & Gly96Cys & $1(0.31 \%)$ & 0 \\
$395 \mathrm{c}>\mathrm{g}$ & Pro132Ala & $1(0.31 \%)$ & 0 \\
$707 \mathrm{c}>\mathrm{g}$ & Arg236Gly & $1(0.31 \%)$ & 0 \\
$642 \mathrm{a}>\mathrm{g}$ & Glu214Gly & $1(0.31 \%)$ & $4(1.07 \%)$ \\
$584 \mathrm{~g}>\mathrm{a}$ & Ala195Thr & $1(0.31 \%)$ & $1(0.27 \%)$ \\
$627 \mathrm{t}>\mathrm{c}$ & Leu209Pro & $1(0.31 \%)$ & 0 \\
$262 \mathrm{c}>\mathrm{a}$ & Phe87Leu & $1(0.31 \%)$ & 0 \\
$273 \mathrm{a}>\mathrm{g}$ & Asn91Ser & 0 & $1(0.27 \%)$ \\
$169 \mathrm{~g}>\mathrm{a}$ & Glu57Lys & 0 & $1(0.27 \%)$ \\
$431 \mathrm{t}>\mathrm{c}$ & Phe144Leu & $1(0.31 \%)$ & 0 \\
POMC gene variations & & $3.72 \%, 95 \%$ CI: $1.66-5.80$ & $2.20 \%, 95 \%$ CI: $0.69-3.71$ \\
frequency & & NS \\
\hline
\end{tabular}

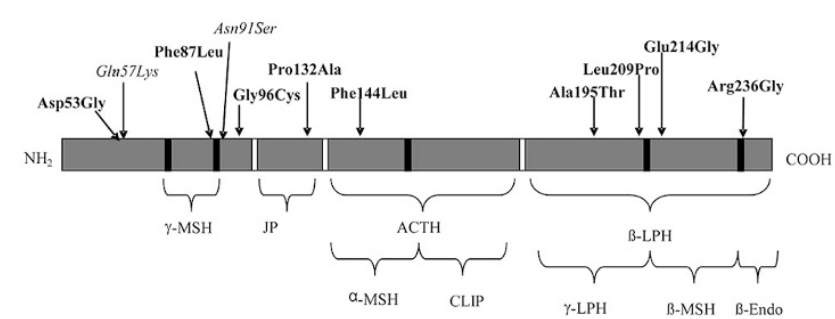

Figure 1. POMC protein and location of the variants in obese and lean children. White and black boxes are for the cut sites for PCs. Italics: mutations identified only in controls. JP, joint peptide; CLIP, corticotropin-like intermediate peptide; LPH, lipoprotein hormone; Endo, endorphin.

other available family members were not carriers of the mutation and were neither overweight nor obese.

Clinical and biologic phenotype of the phe144leu mutation carrier. The Phe144Leu mutation carrier was a 12-y-old obese girl from a nonconsanguineous family. She was born at term and had a normal birth weight (3000 g). She had no red hair and no clinical evidence of adrenal impairment. At age $12 \mathrm{y}$, the patient's BMI $Z$ score was 2.7 SDs with normal puberty (Tanner stage 4). Her fat mass was $31.45 \%(18.7 \mathrm{~kg}$ ) of her total body mass. The BMI curve showed a preserved but early (at age 2 y) adiposity rebound in the absence of any dietary intervention (Fig. 2B). The age at obesity onset, defined as age with BMI above the 97th percentile, was $4.5 \mathrm{y}$. We compared the BMI evolution of the proband with that of subjects lacking leptin receptor (LEPR) signaling and with that of subjects heterozygous for MC4R mutations (24) (Fig. $2 B$ ). In contrast to LEPR-deficient patients, the BMI curve of the proband did not show a dramatic augmentation. When compared with young MC4R mutation carriers (20, unpublished data), the BMI curves were close during the first $4 \mathrm{y}$ of life between MC4R mutation carriers and the girl carrying the Phe144Leu mutation. Differences in BMI evolution markedly appeared after the age of $5 \mathrm{y}$ because the BMI of the POMC mutation carrier showed only minor aggravation compared with MC4R subjects displaying a rapid increase in BMI in the absence of any dietary intervention.

Endocrine and metabolic explorations in the proband showed only a moderate hyperinsulinemia with a plasma insulin level of $16.9 \mu \mathrm{UI} / \mathrm{mL} 120 \mathrm{~min}$ after glucose ingestion with normal glucose levels (Table 3). Hypothalamic-pituitary- adrenal axis explorations were normal (urinary free cortisol, dynamic test of adrenal axis), as well as thyroid axis explorations (free $\mathrm{T}_{4}$ and TSH) (Table 3). Circulating leptin measurement (leptin $20 \mathrm{ng} / \mathrm{mL}$ ) was in agreement with her corpulence (leptin/kg fat mass, 1.1). Lipid metabolism was unremarkable (total cholesterol, $1.7 \mathrm{~g} / \mathrm{L}$; triacylglycerol, 0.9 $\mathrm{mM})$. At age $12 \mathrm{y}$, the resting metabolic rate evaluated by indirect calorimetry was normal for her body composition (1260 kcal /24 h, $39 \mathrm{~kg}$ fat-free mass).

Functional effect of the Phe144leu POMC mutation. We evaluated the ability of Leu $144 \alpha \mathrm{MSH}$ (mutated POMC allele) to activate hMC4R by comparing both cAMP production and the binding to the receptor with that of Phe $144 \alpha \mathrm{MSH}$ (wildtype allele). In our assay, hMC4R activation in response to Leu144 $\alpha \mathrm{MSH}$ was almost completely abolished $\left(\mathrm{EC}_{50}\right.$ not determinable) compared with that with Phe1 $44 \alpha \mathrm{MSH}\left(\mathrm{EC}_{50} \pm\right.$ $\mathrm{SD}=1.5 \pm 0.7 \mathrm{nM}$ ) (Fig. 3A). This result was due, at least partially, to the dramatically altered binding of Leu $144 \alpha \mathrm{MSH}$ to hMC4R (Fig. 3B).

\section{DISCUSSION}

We report here the screening of the POMC gene in a cohort of obese and nonobese French children. A novel mutation (Phe144Leu) located in the $\alpha$ MSH domain of the POMC gene associated with early-onset obesity was detected. In vitro studies revealed that the Phe144Leu amino acid substitution resulted in a deleterious functional effect with a complete lack of hMC4R activation due to a dramatic impairment of mutant $\alpha \mathrm{MSH}$ binding. The Phe144Leu mutation was found in a 12 -y-old girl with early-onset obesity. No other associated phenotypes such as adrenal insufficiency and hypopigmentation were noted in contrast to the phenotype in patients with POMC-null homozygous mutation (4). This may be explained by the complex regulation of pigmentation characterized by high interindividual variability. More specifically, pigmentation in humans varies greatly between individuals and particularly among ethnic groups, primarily because of several differences in melanin (e.g. size, shape, density, and type) and the multiple polymorphisms in melanocortin 1 receptor that are capable of modulating its basal activity (10). Several observations, including this one, suggest that the skin and hair phenotype might vary according to the ethnic origin of POMC 
Table 2. Characteristics of POMC mutations carriers

\begin{tabular}{|c|c|c|c|c|c|c|c|c|c|c|c|}
\hline Subjects & $\begin{array}{l}\text { POMC } \\
\text { mutation }\end{array}$ & $\begin{array}{l}\text { Age } \\
(\mathrm{y})\end{array}$ & Sex & $\begin{array}{l}\text { BMI } Z \\
\text { (SD) }\end{array}$ & $\begin{array}{c}\text { Age at obesity } \\
\text { onset (y) }\end{array}$ & $\begin{array}{c}\text { Ins T0 } \\
(\mu \mathrm{U} / \mathrm{mL})\end{array}$ & $\begin{array}{c}\text { Gly T0 } \\
(\mathrm{mmol} / \mathrm{L})\end{array}$ & HOMA & $\begin{array}{c}\mathrm{TG} \\
(\mathrm{mmol} / \mathrm{L})\end{array}$ & $\begin{array}{l}\text { Chol } \\
(\mathrm{g} / \mathrm{L})\end{array}$ & $\begin{array}{r}\text { Leptin } \\
(\mathrm{ng} / \mathrm{mL})\end{array}$ \\
\hline \multicolumn{12}{|l|}{ Obese } \\
\hline 1 & Asp53Gly & 5 & $\mathrm{~F}$ & 4.7 & 5 & 4.1 & 4.3 & 0.8 & 0.5 & 0.7 & ND \\
\hline 2 & Asp53Gly & 7 & M & 6.7 & 0.5 & 13.0 & 5.1 & 3.0 & 0.6 & 1.7 & 17.5 \\
\hline 3 & Asp53Gly & 8 & M & 5.2 & 4 & 14.0 & 4.8 & 3.0 & 0.5 & 1.5 & 16.0 \\
\hline 4 & Asp53Gly & 10 & $\mathrm{~F}$ & 4.7 & 6 & 19.8 & 4.8 & 4.2 & 1.3 & 2.1 & 26.0 \\
\hline 5 & Gly96Cys & 13 & $\mathrm{~F}$ & 3.6 & $?$ & 14.0 & 4.9 & 3.0 & 0.8 & 1.4 & 21.0 \\
\hline 6 & Pro132Ala & 17 & F & 3.8 & $?$ & 16.9 & 5.0 & 3.7 & 0.9 & 1.5 & ND \\
\hline 7 & Arg236Gly & 15 & $\mathrm{~F}$ & 1.7 & 5 & ND & ND & ND & ND & ND & ND \\
\hline 8 & Glu214Gly & 11 & $\mathrm{~F}$ & 3.3 & 2 & 26.0 & 4.9 & 5.7 & 0.8 & 0.9 & 12.0 \\
\hline 9 & Ala195Thr & 12 & $\mathrm{~F}$ & 5.8 & $?$ & ND & ND & ND & ND & ND & ND \\
\hline 10 & Leu209Pro & 14 & M & 3.9 & 3.2 & 18.0 & 5.1 & 4.1 & 0.8 & 1.5 & 19.4 \\
\hline 11 & Phe87Leu & 7 & $\mathrm{~F}$ & 6.2 & $?$ & 15.0 & 5.0 & 3.3 & 0.6 & 1.8 & 21.0 \\
\hline 12 & Phe144Leu & 12 & $\mathrm{~F}$ & 2.7 & 4.5 & 8.3 & 5.5 & 2.0 & 0.9 & 1.7 & 20.0 \\
\hline \multicolumn{12}{|l|}{ Controls } \\
\hline 13 & Asn91Ser & 11 & M & -1.1 & - & 5.9 & 4.8 & 1.3 & 0.4 & 1.2 & 3.9 \\
\hline 14 & Glu57Lys & 11 & M & 0.3 & - & 15.5 & 4.1 & 2.9 & 0.8 & 1.1 & 3.5 \\
\hline 15 & Asp53Gly & 12 & M & 0.9 & - & ND & ND & ND & ND & 1.2 & 4.2 \\
\hline 16 & Glu214Gly & 13 & M & 1.6 & - & 15.0 & 5.7 & 3.8 & 1.1 & 1.4 & 21.4 \\
\hline 17 & Glu214Gly & 12 & $\mathrm{~F}$ & 0.1 & - & 4.2 & 4.7 & 0.9 & 0.8 & 1.5 & 8.6 \\
\hline 18 & Glu214Gly & 11 & $\mathrm{~F}$ & 3.9 & - & 23.2 & 5.1 & 5.2 & 1.3 & 1.1 & 40.8 \\
\hline 19 & Glu214Gly & 12 & M & -1.2 & - & 5.2 & 4.9 & 1.1 & 0.4 & 1.7 & 0.8 \\
\hline 20 & Ala195Thr & 14 & $\mathrm{~F}$ & 0.8 & - & ND & ND & ND & ND & ND & 16.8 \\
\hline
\end{tabular}

M, male, F, female; age at obesity onset is defined as age with BMI above the 97th percentile; Ins T0, fasting insulinemia; Gly T0: fasting glucose; HOMA, homeostasis model assessment index defined as (fasting insulin level $\times$ fasting glucose level) divided by 22.5; TG, triacylglycerol; Chol, total cholesterol; ?, data not available; ND, not determined.

Biological parameters were measured according to methods described in Materials and Methods section.

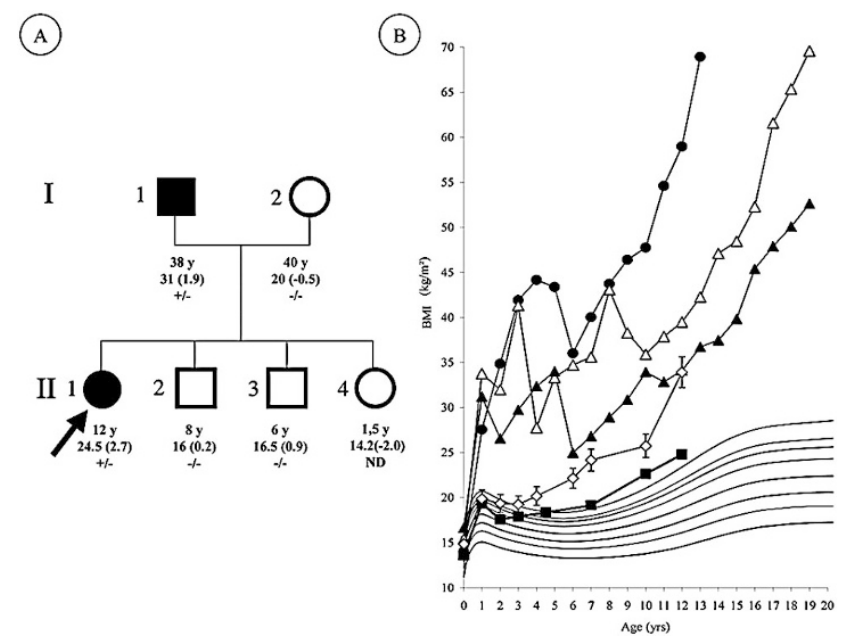

Figure 2. Pedigree, genotype, and clinical characteristics of the Phe144Leu POMC mutation carrier. (A) Pedigree and genotypes. The proband II1 is a 12-y-old female with a BMI of $22.5 \mathrm{~kg} / \mathrm{m}^{2}$ (BMI Z score $=2.7 \mathrm{SDs})$. She is heterozygous for a Phe144Leu $(\mathrm{t}>\mathrm{c} 431)$ mutation. The mutated allele was transmitted by her father who is moderately obese (BMI, $31 \mathrm{~kg} / \mathrm{m}^{2}$ at age $38 \mathrm{y}$, BMI $Z$ score $\left.=1.9 \mathrm{SDs}\right)$. Subjects I2 (BMI, $21 \mathrm{~kg} / \mathrm{m}^{2}$ at age $40 \mathrm{y}$, BMI $Z$ score $=-0.5 \mathrm{SD}$ ), II2 (age, $8 \mathrm{y}$; BMI $Z$ score $=0.2 \mathrm{SD}$ ) and II3 (age, $6 \mathrm{y}$; BMI $Z$ score $=0.9$ $\mathrm{SD}$ ) are nonobese carriers of two normal alleles. Obese individuals (solid circles and squares). Age, BMI $Z$ score, and genotype (+, normal; -, mutated) are indicated on the pedigree; ND, not determined. (B) BMI curves of the proband (HetPOMC), six heterozygous MC4R mutation carriers (HetMC4R), and three homozygous null leptin receptor mutants (LepR 1, 2, 3). HetPOMC (solid squares); LepR 1 (solid circles); LepR 2 (open triangles); LepR 3 (solid triangles); HetMC4R (open diamonds).

mutation carriers $(5,17)$. Precise chemical analysis measuring hair melanin peptide and skin pigmentation would be necessary to firmly conclude. We also observed normal results in hypothalamic-pituitary-adrenal axis explorations in the Phe144Leu carrier, which could be explained by the fact that the mutation does not alter the effect of ACTH on melanocortin 2 receptor. This is in agreement with previous findings observed in heterozygous carriers of POMC mutations $(5,12,17,18)$. However, this would need further in vitro functional investigation.

The BMI curve of this subject shows several interesting findings. Obesity starts as early as in the MC4R mutant carriers, suggesting a very early effect of the functionally relevant Phe144leu mutation on weight gain after birth. However, it is less severe over time. This is not due to a change in diet because both MC4R and POMC mutated subjects did not undergo any dietary intervention until the age of $10 \mathrm{y}$. This observation suggests that, in humans, deleterious heterozygous mutations in the $\alpha \mathrm{MSH}$ domain of the POMC gene might lead to a less severe obese phenotype than heterozygous mutations in MC4R gene. While the central melanocortin system is intolerant to the loss of a single MC4R allele, it appears to be able to tolerate the loss of one copy of the POMC gene, except for mutations in $\beta$ MSH. The Phe144Leu mutation in $\alpha \mathrm{MSH}$, as the one recently reported by Lee $e t$ al. (18), appears to have only a moderate effect on the obese phenotype when compared with the effect of $\beta \mathrm{MSH}$ mutations. Our findings provide additional support for a more critical role of $\beta \mathrm{MSH}$ than of $\alpha \mathrm{MSH}$ in the control of human energy balance $(12,17,18)$. Because $\beta \mathrm{MSH}$ is present in the human hypothalamus (25) and seems to have higher affinity for the hMC4R (26), it is likely to be the more physiologically relevant endogenous ligand for the hMC4R (when compared with $\alpha \mathrm{MSH}$ ). The obese phenotype associated with the POMC 
Table 3. Endocrine characteristics of the proband with the Phe144Leu mutation

\begin{tabular}{lcc}
\hline & Phe144Leu & Normal range \\
\hline UFC $(\mu \mathrm{g} / 24 \mathrm{~h})$ & 17.5 & $23 \pm 11$ \\
CRF test & & \\
Cortisol $(\mathrm{ng} / \mathrm{mL})(0-60 \mathrm{~min})$ & $53-146$ & $104 \pm 48-184 \pm 29$ \\
$\mathrm{ACTH}(\mathrm{pg} / \mathrm{mL})(0-60 \mathrm{~min})$ & $25-76$ & $<40-77 \pm 27$ \\
$\mathrm{LPH}(\mathrm{pg} / \mathrm{mL})(0-60 \mathrm{~min})$ & $124-218$ & $87 \pm 38-167 \pm 49$ \\
$\mathrm{TSH}(\mu \mathrm{U} / \mathrm{mL})$ & 3.0 & $1.78(0.2-3.5)$ \\
Free $\mathrm{T}_{4}(\mathrm{pg} / \mathrm{mL})$ & 7.2 & $8.5(5.8-11.5)$ \\
OGTT & & T0: $3.3-5.8 ; \mathrm{T} 120:<7.8$ \\
Glucose $(\mathrm{mmol} / \mathrm{L})(0-30-120 \mathrm{~min})$ & $5.0-7.2-6.5$ & $\mathrm{~T} 0:<5$ \\
Insulinemia $(\mu \mathrm{UL} / \mathrm{mL})(0-30-120 \mathrm{~min})$ & $8.3-32.2-16.9$ & \\
\hline
\end{tabular}

UFC, urinary free cortisol; CRF, corticotropin releasing factor; LPH, lipoprotein hormone; OGTT, oral glucose tolerance test.
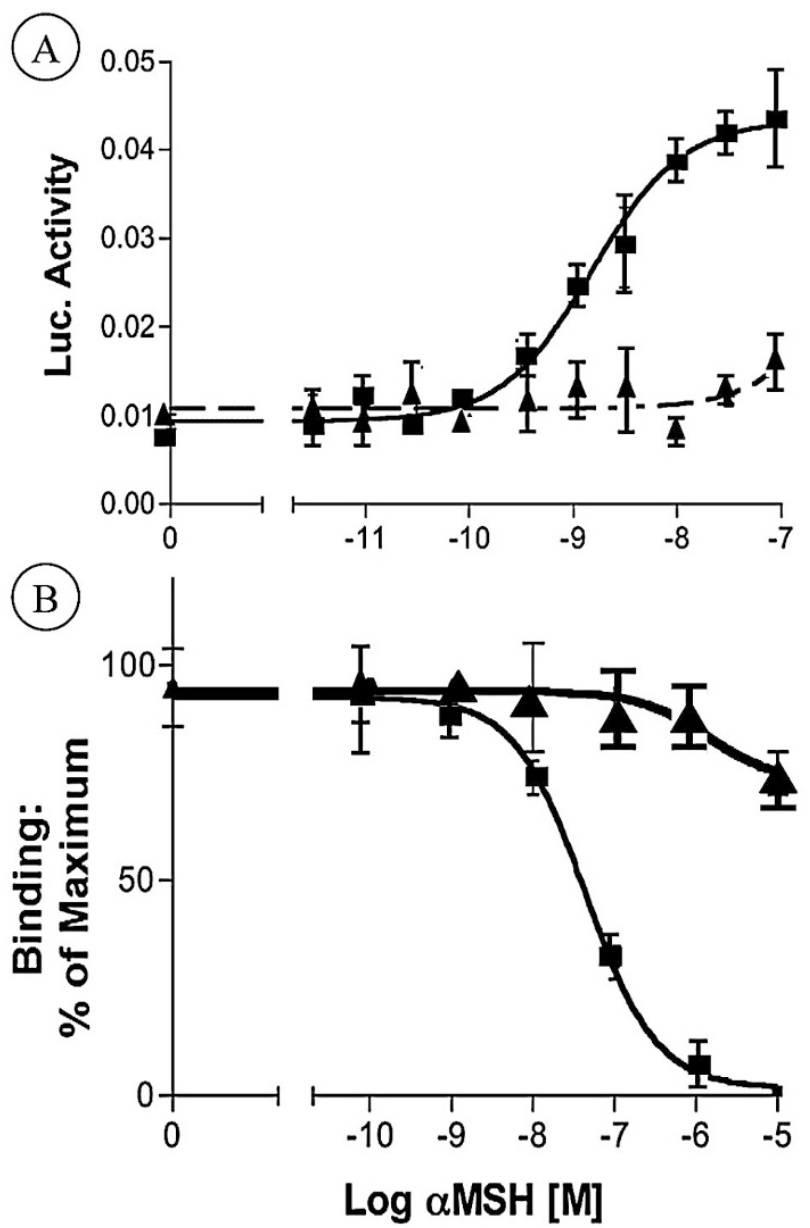

Figure 3. Impaired activation and binding of MC4R by the $\alpha \mathrm{MSH}$ product of Phe144Leu POMC. Leu144 $\alpha$ MSH (Leu at position 7 of $\alpha$ MSH corresponding to the mutated POMC allele) and Phe $144 \alpha \mathrm{MSH}$ (Phe at position 7 corresponding to wild type) were synthesized and purified by highperformance liquid chromatography. (A) MC4R activity in response of Phe $144 \alpha$ MSH or Leu $144 \alpha$ MSH. Data points represent means of five determinations and error bars indicate SDs. The $\mathrm{EC}_{50} \pm \mathrm{SDs}$ for $\alpha \mathrm{MSH}$ activation is $1.5 \pm 0.7 \mathrm{nM}$. $(B)$ Competition binding assay of Phe $144 \alpha$ MSH or Leu144 $\alpha$ MSH on the human MC4R. Each point is the mean of triplicate values and error bars indicate $\mathrm{SDs}$. The $\mathrm{IC}_{50}$ for Phe $144 \alpha \mathrm{MSH}$ in this experiment is $29.6 \pm 7.52 \mathrm{nM}$. Phe $144 \alpha \mathrm{MSH}$ (solid squares); Leu $144 \alpha \mathrm{MSH}$ (solid triangles).

mutation reported here could also be modulated by other variants in modifier genes, intrinsic and/or extrinsic to the melanocortin pathway. Cosegregation analysis also showed that the obese father carrying the mutation has a comparatively less pronounced form of obesity. Gene-environment interactions are a plausible explanation, as the younger generation is growing up in a much more obesogenic environment compared with the older generation. This family pedigree with the POMC mutation further illustrates the complex nature of human obesity when variant alleles in certain "thrifty" genes might interact together to favor weight gain in a predisposing environment.

In our study, the frequency of POMC gene variations was not significantly different between obese and control children. In contrast to MC4R mutations that are significantly more frequent in obese populations $(27,28)$, it suggests that the implication of POMC mutations in the development of obesity remains to be discussed. Although carriers of POMC mutations have been described in several studies $(4,5,11-13,16-$ 18), the effect of the mutations on the obesity phenotype appears to be variable and the study of the functional consequences of POMC mutations are still rare but necessary to demonstrate their pathogenic role. Up to now, only a few POMC mutations may be considered a cause of monogenic obesity $(4,12,17,18)$.

In conclusion, we found a similar frequency of POMC mutations in lean and obese children. Only rare deleterious mutations, such as the Phe144Leu described here, might contribute to early-onset obesity $(11-13,16-18)$. In addition to previous studies, our findings confirm the less critical role of the POMC gene mutations in the complex determinism of human obesity when compared with MC4R mutations that are involved in $2 \%-3 \%$ of human obesity $(27,28)$. In addition, they may confirm the more critical role of $\beta \mathrm{MSH}$ than $\alpha \mathrm{MSH}$ in the control of human energy balance because mutations in $\alpha \mathrm{MSH}$ appear to have only a moderate effect on the obese phenotype when compared with the effect of $\beta \mathrm{MSH}$ mutations and support the physiologic role of the melanocortin pathway in human weight regulation.

Acknowledgments. The authors are grateful to the medical staff of Pediatric Departments (Trousseau, Caen, Margency) for patient recruitment and to Pr. Yves Lebouc and his staff for endocrine explorations. They also thank the ATC Nutrition INSERM. Investigations were performed in the Center of Research on Human Nutrition (CRNH).

\section{REFERENCES}

1. Cone RD 2006 Studies on the physiological functions of the melanocortin system. Endocr Rev 27:736-749 
2. Seeley RJ, Drazen DL, Clegg DJ 2004 The critical role of the melanocortin system in the control of energy balance. Annu Rev Nutr 24:133-149

3. Slominski A, Plonka PM, Pisarchik A, Smart JL, Tolle V, Wortsman J, Low MJ 2005 Preservation of eumelanin hair pigmentation in proopiomelanocortin-deficient mice on a nonagouti (a/a) genetic background. Endocrinology 146:1245-1253

4. Krude H, Biebermann H, Luck W, Horn R, Brabant G, Gruters A 1998 Severe early-onset obesity, adrenal insufficiency and red hair pigmentation caused by POMC mutations in humans. Nat Genet 19:155-157

5. Farooqi IS, Drop S, Clements A, Keogh JM, Biernacka J, Lowenbein S, Challis BG, O'Rahilly S 2006 Heterozygosity for a POMC-null mutation and increased obesity risk in humans. Diabetes 55:2549-2553

6. Comuzzie AG, Hixson JE, Almasy L, Mitchell BD, Mahaney MC, Dyer TD, Stern MP, MacCluer JW, Blangero J 1997 A major quantitative trait locus determining serum leptin levels and fat mass is located on human chromosome 2. Nat Genet $15: 273-276$

7. Hager J, Dina C, Francke S, Dubois S, Houari M, Vatin V, Vaillant E, Lorentz N, Basdevant A, Clement K, Guy-Grand B, Froguel P 1998 A genome-wide scan for human obesity genes reveals a major susceptibility locus on chromosome 10. Nat Genet 20:304-308

8. Rotimi CN, Comuzzie AG, Lowe WL, Luke A, Blangero J, Cooper RS 1999 The quantitative trait locus on chromosome 2 for serum leptin levels is confirmed in African-Americans. Diabetes 48:643-644

9. Hixson JE, Almasy L, Cole S, Birnbaum S, Mitchell BD, Mahaney MC, Stern MP, MacCluer JW, Blangero J, Comuzzie AG 1999 Normal variation in leptin levels in associated with polymorphisms in the proopiomelanocortin gene, POMC. J Clin Endocrinol Metab 84:3187-3191

10. Carroll L, Voisey J, van Daal A 2005 Gene polymorphisms and their effects in the melanocortin system. Peptides 26:1871-1885

11. Hinney A, Becker I, Heibult O, Nottebom K, Schmidt A, Ziegler A, Mayer H, Siegfried W, Blum WF, Remschmidt H, Hebebrand J 1998 Systematic mutation screening of the pro-opiomelanocortin gene: identification of several genetic variants including three different insertions, one nonsense and two missense point mutations in probands of different weight extremes. J Clin Endocrinol Metab 83:3737-3741

12. Biebermann $\mathrm{H}$, Castaneda TR, van Landeghem F, von Deimling A, Escher F, Brabant G, Hebebrand J, Hinney A, Tschop MH, Gruters A, Krude H 2006 A role for beta-melanocyte-stimulating hormone in human body-weight regulation. Cell Metab 3:141-146

13. Echwald SM, Sorensen TI, Andersen T, Tybjaerg-Hansen A, Clausen JO, Pedersen O 1999 Mutational analysis of the proopiomelanocortin gene in Caucasians with early onset obesity. Int J Obes Relat Metab Disord 23:293-298

14. Suviolahti E, Ridderstrale M, Almgren P, Klannemark M, Melander O, Carlsson E, Carlsson M, Hedenbro J, Orho-Melander M 2003 Pro-opiomelanocortin gene is associated with serum leptin levels in lean but not in obese individuals. Int J Obes Relat Metab Disord 27:1204-1211

15. Miraglia del Giudice E, Cirillo G, Santoro N, D’Urso L, Carbone MT, Di Toro R, Perrone L 2001 Molecular screening of the proopiomelanocortin (POMC) gene in Italian obese children: report of three new mutations. Int J Obes Relat Metab Disord 25:61-67

16. Buono P, Pasanisi F, Nardelli C, Ieno L, Capone S, Liguori R, Finelli C, Oriani G, Contaldo F, Sacchetti L 2005 Six novel mutations in the proopiomelanocortin and melanocortin receptor 4 genes in severely obese adults living in southern Italy. Clin Chem 51:1358-1364

17. Challis BG, Pritchard LE, Creemers JW, Delplanque J, Keogh JM, Luan J, Wareham NJ, Yeo GS, Bhattacharyya S, Froguel P, White A, Farooqi IS, O'Rahilly S 2002 A missense mutation disrupting a dibasic prohormone processing site in proopiomelanocortin (POMC) increases susceptibility to early-onset obesity through a novel molecular mechanism. Hum Mol Genet 11:1997-2004

18. Lee YS, Challis BG, Thompson DA, Yeo GS, Keogh JM, Madonna ME, Wraight V, Sims M, Vatin V, Meyre D, Shield J, Burren C, Ibrahim Z, Cheetham T, Swift P, Blackwood A, Hung CC, Wareham NJ, Froguel P, Millhauser GL, O'Rahilly S, Faroogi IS 2006 A POMC variant implicates beta-melanocyte-stimulating hormone in the control of human energy balance. Cell Metab 3:135-140

19. Delplanque J, Barat-Houari M, Dina C, Gallina P, Clement K, Guy-Grand B Vasseur F, Boutin P, Froguel P 2000 Linkage and association studies between the proopiomelanocortin (POMC) gene and obesity in Caucasian families. Diabetologia 43:1554-1557

20. Dubern B, Clement K, Pelloux V, Froguel P, Girardet JP, Guy-Grand B, Tounian P 2001 Mutational analysis of melanocortin-4 receptor, agouti-related protein, and alpha-melanocyte-stimulating hormone genes in severely obese children. J Pediatr 139:204-209

21. Rolland-Cachera MF, Cole TJ, Sempe M, Tichet J, Rossignol C, Charraud A 1991 Body mass index variations: centiles from birth to 87 years. Eur J Clin Nutr 45:13-21

22. Simon C, Wagner A, DiVita C, Rauscher E, Klein-Platat C, Arveiler D, Schweitzer B, Triby E 2004 Intervention centred on adolescents' physical activity and sedentary behaviour (ICAPS): concept and 6-month results. Int J Obes Relat Metab Disord 28:S96-S103

23. Lubrano-Berthelier C, Durand E, Dubern B, Shapiro A, Dazin P, Weill J, Ferron C, Froguel P, Vaisse C 2003 Intracellular retention is a common characteristic of childhood obesity-associated MC4R mutations. Hum Mol Genet 12:145-153

24. Clement K, Vaisse C, Lahlou N, Cabrol S, Pelloux V, Cassuto D, Gourmelen M, Dina C, Chambaz J, Lacorte JM, Basdevant A, Bougneres P, Lebouc Y, Froguel P, Guy-Grand B 1998 A mutation in the human leptin receptor gene causes obesity and pituitary dysfunction. Nature 392:398-401

25. Bertagna X, Lenne F, Comar D, Massias JF, Wajcman H, Baudin V, Luton JP, Girard F 1986 Human beta-melanocyte-stimulating hormone revisited. Proc Natl Acad Sci U S A 83:9719-9723

26. Harrold JA, Williams G 2006 Melanocortin-4 receptors, beta-MSH and leptin: key elements in the satiety pathway. Peptides 27:365-371

27. Lubrano-Berthelier C, Dubern B, Lacorte JM, Picard F, Shapiro A, Zhang S, Bertrais S, Hercberg S, Basdevant A, Clement K, Vaisse C 2006 Melanocortin 4 receptor mutations in a large cohort of severely obese adults: prevalence, functional classification, genotype-phenotype relationship, and lack of association with binge eating. J Clin Endocrinol Metab 91:1811-1818

28. Hinney A, Bettecken T, Tarnow P, Brumm H, Reichwald K, Lichtner P, Scherag A Nguyen TT, Schlumberger P, Rief W, Vollmert C, Illig T, Wichmann HE, Schafe H, Platzer M, Biebermann H, Meitinger T, Hebebrand J 2006 Prevalence, spectrum, and functional characterization of melanocortin- 4 receptor gene mutations in a representative population-based sample and obese adults from Germany. J Clin Endocrinol Metab 91:1761-1769 